\title{
Tehnička izvedba infrastrukture i ostali sadržaji u parkovima prirode Lonjsko polje i Medvednica
}

\author{
Tea Jakobašić, Zdravka Klišanin, Hrvoje Nevečerel, Kruno Lepoglavec
}

\begin{abstract}
Nacrtak - Abstract
Šume $i$ šumsko zemljište danas pružaju višestruku korist čovjeku koji obitava u prirodi. Ubrzan i stresan način života čovjeku nameće potrebu da se skloni daleko od gradske gužve, a upravo se takva mjesta sve češće nalaze u parkovima prirode. Šume parka prirode uistinu mogu dati traženi mir posjetitelju, a Lonjsko polje i Medvednica su dva parka koja se sastoje od velikih, ali različitih šumskih površina. Također su to dva vrlo zanimljiva parka prirode, svaki specifičan na svoj način. Park prirode Medvednica rekreacijsko je područje u neposrednoj blizini milijunske gradske aglomeracije koji pruža velike mogućnosti za razvoj rekreacijskih aktionosti. Šume na Medvednici ne služe samo za proizvodnju dronih sortimenata, nego ih istodobno građani grada Zagreba i ostali ljudi koriste za svoju svakodnevnu rekreaciju. Pristup Parku prirode Medvednica omogućen je pješacima, biciklistima, posjetitelji mogu doći $i$ osobnim automobilima i javnim prijevozom (autobus), a uskoro će u pogonu biti i žičara. Sadržaji koji se nude posjetiteljima su: poučne staze, planinarske staze, interpretativne šetnje, posjet Medvedgradu, špilji Veternici $i$ rudniku Zrinski. Uz to, tu su i ugostiteljsko-smještajni kapaciteti te planinarski domovi. Park prirode Lonjsko polje je poplavno područje u kojemu dominiraju hrast lužnjak, crna joha, poljski jasen i nizinski brijest. Izgrađene su pješačke i edukativne staze, prihvatni centri, suvenirnice, osigurana plovidba čamcima iz pristaništa u Krapju, ali i povezanost autobusnim linijama. Ta infrastruktura $i$ sadržaji, uključujući i edukativne programe, osnova su za pružanje višednevne usluge i zadržavanje posjetitelja na tom području. Posjetitelji u najvećem postotku uz pješačenje koriste vidikovce $i$ promatranje ptica kao rekreativni sadržaj u Parku prirode Lonjsko polje. U članku se kroz opis svakog pojedinog parka prirode ukazuje na bitne razlike između ta dva područja, ali i sličnosti koje ih na neki način povezuju.
\end{abstract}

Ključne riječi: park prirode, Medvednica, Lonjsko polje, oblikovanje parkovnih prostora, šumarstvo, rekreacija

\section{Uvod - Introduction}

Općekorisne funkcije odnose se na zaštitnu ulogu šuma na režim voda, na šume kao najznačajnijega proizvođača kisika, na povoljno djelovanje $u$ zdravstvenom pogledu, posebno $u$ psihičkom ili, ukratko, kao područje ili mjesto vrlo pogodno za rekreaciju i odmor. U posljednje vrijeme potreba za rekreacijom na otvorenome sve je izraženija. Razlog je tomu današnji način života, odnosno stresni način života, gdje čovjek traži neko mirno mjesto, daleko od buke i gužve. Zaštićena područja sve su popularnija za stanovništvo te imaju sve važniju turističku i rekreativnu ulogu u svakodnevnom životu čovjeka. Međunarodni savez za očuvanje prirode (IUCN) navodi kako su turizam i rekreacija vrlo visoko pozicionirani među ciljevima upravljanja u različitim kategorijama zaštićenih područja kao elementima prirodne baštine (IUCN 2021). Parkovi prirode su jedni od najznačajnijih zaštićenih turističkih područja i zauzimaju veliku površinu u Hrvatskoj od visokog interesa za posjetitelje. Parkovi prirode su prostrana prirodno ili dijelom kultivirana područja kopna i/ili mora velike bioraznolikosti i/ili georaznolikosti, s vrijednim ekološkim obilježjima, naglašenim krajobraznim i kulturno-povijesnim 
vrijednostima. Park prirode ima znanstvenu, kulturnu, odgojno-obrazovnu i rekreativnu namjenu, a u njemu su dopuštene gospodarske i druge djelatnosti te zahvati kojima se ne ugrožavaju njihova bitna obilježja i uloga (MINGOR 2021).

U Parku prirode Medvednica glavna su značajka šume (bukve, jele, javora, jasena i hrasta kitnjaka) velike biološke vrijednosti uslijed čega je unutar parka zaštićeno 8 šumskih rezervata. Zbog razlika u visini kao i zbog prisustva brojnih potoka i izvora, ovaj prostor karakteriziraju raznolika staništa koja su zaslužna za bogat biljni i životinjski svijet. U parku je zabilježeno preko 1300 biljnih vrsta, a zbog raznolikosti šuma ptičji svijet broji 70 gnjezdarica. Medvednicu obilježava i raznolikost geološke građe. Najpoznatija stijena Medvednice je zeleni škriljevac, dok su karbonatne stijene zaslužne za nastanak $7100 \mathrm{~m}$ dugog kanala špilje Veternice koja je jedno od naših najznačajnijih paleontoloških nalazišta (MINGOR 2021).

Park prirode Lonjsko polje najveće je zaštićeno poplavno područje cijelog dunavskog sliva s vrijednim krajobraznim i ekološkim obilježjima. Posebnu ljepotu krajoliku daju poplavne šume hrasta lužnjaka i slikoviti vlažni pašnjaci sa starim nastambama ispresijecani mrežom vodenih površina. Rukavci, bare i vlažne livade staništa su ptica močvarica poput žličarke, male bijele čaplje, patke njorke, orla štekavca, orla kliktaša, crne rode, prdavca i bjelobrade čigre, vrsta rijetkih ili već izumrlih u mnogim dijelovima Europe. Do sada je ovdje zabilježeno 250 vrsta ptica, od kojih se 170 vrsta tu i gnijezdi. Iz tog razloga pojedina područja u parku: Krapje Đol i Rakita zaštićena su kao posebni ornitološki rezervati, a cijelo područje parka uvršteno je 1983. g. na Listu važnih ornitoloških područja Europe (IBA). Od 1993. godine park se nalazi na Popisu vlažnih staništa od međunarodnog značaja Konvencije o zaštiti vlažnih staništa RAMSAR (MINGOR 2021).

Kod upravljanja takvim područjem bitno je definirati različite zone sa usmjeravanjem svih gospodarskih i razvojnih aktivnosti na način da se očuvaju krajobrazne i ambijentalne vrijednosti te na najmanju moguću mjeru svede negativni utjecaj na cjelokupno zaštićeno područje. Naravno da takav pristup na nekim dijelovima omogućuje građenje novih infrastrukturnih sadržaja, ali i održavanje postojećih, dok negdje nije dopuštena znatnija promjena staništa ni okruženja. Za parkove je važno prilikom planiranja obratiti pažnju da bitni sadržaji budu dostupni svim posjetiteljima, tako i osobama s invaliditetom. Kao dobar primjer u Hrvatskoj se ističu: špilja Vrelo u Fužinama, štetnica u parku prirode Kopački rit, poučna staza "Bliznec« u Parku prirode Medvednica, te poučna staza »Kraljev put« na Petrovoj gori. Navedeni primjeri su samo iz kontinentalnog dijela Hrvatske, jer se na obali najveći dio pozornosti posvećuje plažama, kupalištima i šetnicama (Ožura i dr. 2012).

\section{Područje proučavanja - Research area}

Šume parka prirode imaju vrlo značajnu ulogu u zaštiti čovjekova okoliša. Industrijskim zagađenjem, prometom i drugim zagađivačima šume su oštećene više od $50 \%$ pa je potrebno zaustaviti lokalne emisije. Korištenje parka prirode potrebno je prilagoditi sadašnjemu stanju šumskih ekosustava i obnavljati oštećene šume. Prva i najvažnija mjera radi jačanja i unaprjeđivanja općekorisnih funkcija šuma jest osnivanje fondova za pošumljavanje, melioraciju degradiranih šuma i šikara, za njihovo održavanje, njegu i obnovu, za što bi uz šumarstvo trebali obavezno unositi odgovarajuća sredstva zaštićeni privredni objekti, zdravstvo, proračuni općina i države, vodoprivreda, elektroprivreda, poljoprivreda i dr. - dakle svi koji izravno ili neizravno imaju koristi od šuma (Majer 1980). Najznačajniji fenomen Parka prirode Medvednica su šume koje prekrivaju $81 \%$ površine Parka. Parku prirode Medvednica glavna su značajka šume (bukove, jelove, javorove, jasenove i hrasta kitnjaka) velike biološke vrijednosti zbog čega je u Parku zaštićeno osam šumskih rezervata. Zbog razlika u visini i zbog prisutnosti brojnih potoka i izvora taj prostor karakteriziraju raznolika staništa koja su zaslužna za bogat biljni i životinjski svijet (PP Medvednica 2021). Park prirode Lonjsko polje najveće je zaštićeno poplavno područje cijeloga dunavskoga slijeva s vrijednim krajobraznim i ekološkim obilježjima. Vegetacija istraživanoga područja pripada nizinskomu ili planarnomu vegetacijskomu pojasu koji se prostire na visini od 80 do 150 metara, jer je i sav prostor Lonjskoga polja ispod nadmorske visine od $150 \mathrm{~m}$. Taj je prostor početna razina vertikalnoga pridolaska šumske vegetacije i obilježavaju ga u prvom redu šume hrasta lužnjaka, poljskoga jasena, crne johe, vrba i topola, a nastanak i opstanak je uglavnom u vezi s površinskom i podzemnom vodom. Posebnu ljepotu krajoliku daju poplavne šume hrasta lužnjaka i slikoviti vlažni pašnjaci sa starim nastambama ispresijecani mrežom vodenih površina (PP Lonjsko polje 2021). 


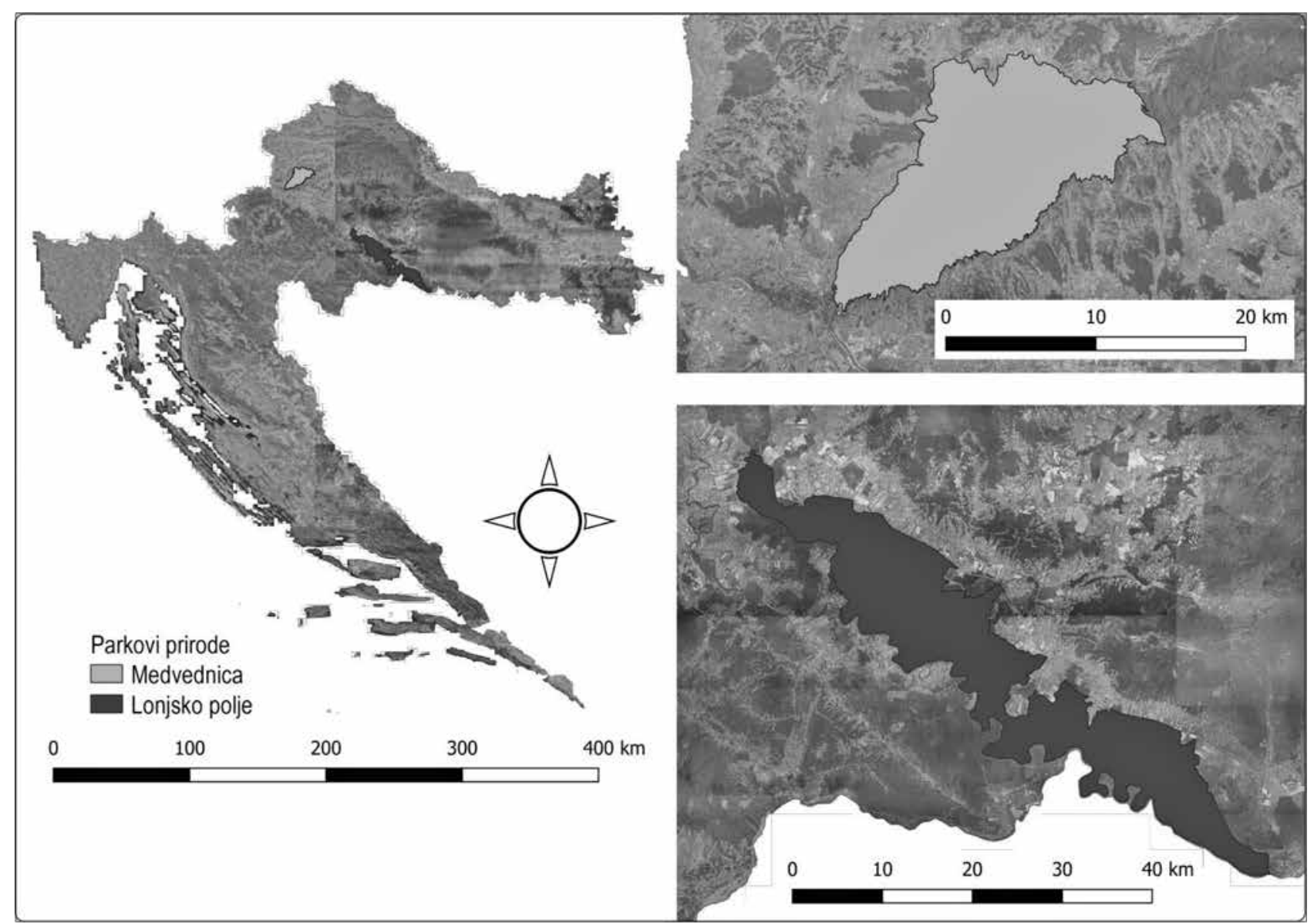

Slika 1. Područje Parka prirode Medvednica i Parka prirode Lonjsko polje

Fig. 1 The area of Medvednica Nature Park and Lonjsko Polje Nature Park

\section{Park prirode Medvednica-Medvednica Nature Park}

Park prirode Medvednica rekreacijsko je područje u neposrednoj blizini milijunske gradske aglomeracije koje pruža velike mogućnosti za razvoj rekreacijskih aktivnosti. Šume na Medvednici ne služe samo za proizvodnju drvnih sortimenata nego ih istodobno građani grada Zagreba i ostali ljudi koriste za svoju rekreaciju. Osim toga te šume zaštićuju grad u sanitarno-higijenskom pogledu - to su "pluća grada Zagreba", one povoljno utječu na klimu i na režim voda i vodotoka, sprječavaju bujice i erozije, u njima životinje, divljač i ptice nalaze svoje sklonište i svoju hranu - jednom riječju šume su na Medvednici dekor grada Zagreba, koje pružaju višestruke koristi počevši od drva, paše i lova do zaštitnih i rekreacijskih funkcija koje one imaju (Klepac 1964). Rekreacijske i edukacijske aktivnosti na Medvednici odvijaju se tijekom cijele godine. Pješačenje, planinarenje, slobodno penjanje, biciklizam, skija- nje, sanjkanje, paintball, zmajarenje, posjećivanje različitih sportskih i kulturnih manifestacija, terenski edukativni programi, terenska nastava za studente sastavnicâ Sveučilišta i za veleučilištâ, programi »Škola u prirodi« za učenike osnovnih i srednjih škola te izviđačkih aktivnosti samo su neke od rekreacijskih i edukacijskih aktivnosti koje se odvijaju u Parku prirode Medvednica. Unutar prostranoga šumskoga kompleksa (78 \% površine Parka prirode) najvrjedniji dijelovi izdvojeni su kao šumski rezervati, dok je ostali dio šume rekreacijska zona. Prema Planu upravljanja u Parku prirode Medvednica mogu se izdvojiti tri zone: I. zona stroge zaštite, II. zona aktivne zaštite te III. zona korištenja. Rekreacijske aktivnosti odvijaju se u zoni aktivne zaštite i u zoni korištenja. U posebnu podzonu aktivne zaštite uključena su područja intenzivnijega posjećivanja te gušće raspoređene posjetiteljske infrastrukture i sadržaja za posjetitelje. Taj prostor obuhvaća šire područje vršne zone i livade koje služe kao skijališta (Opačić i dr. 2014). Park prirode Medvednica zauzi- 
ma površinu od 17938 ha, a teritorijalno je razgraničen između Krapinsko-zagorske, Zagrebačke županije i Grada Zagreba. Velik utjecaj na sam izgled Parka i na sadržaje koje nudi ima poveći broj posjetitelja, ali i ljudi koji žive u granicama Parka (prema procjeni iz 2001. godine u Parku je živjelo 7400 ljudi). Sve izraženija rekreacijska, ali i edukacijska funkcija Parka dovele su do rastućega broja sadržaja, programa i usluga za posjetitelje. Javna ustanova »Park prirode Medvednica " proteklih je godina uredila čak sedam poučnih staza, od kojih je Šumska staza Bliznec prilagođena osobama s invaliditetom, devet novih biciklističkih staza (osam kružnih i jedna transverzalna, otvorene u svibnju 2013), koje su prilagođene različitim kategorijama tjelesne spremnosti rekreativaca, kao i infopunktove na glavnim ulazima u Park (Bliznec, Pila i Bistra). Pristup Parku

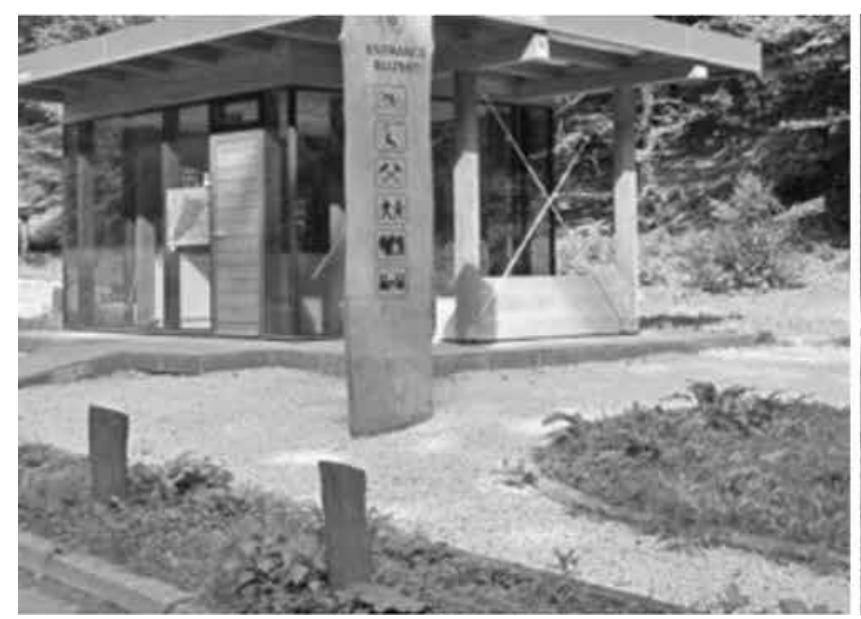

Slika 2. Ulaz u Park prirode Medvednica - infocentar Bliznec Fig. 2 Entrance to Medvednica Nature Park - Bliznec info center
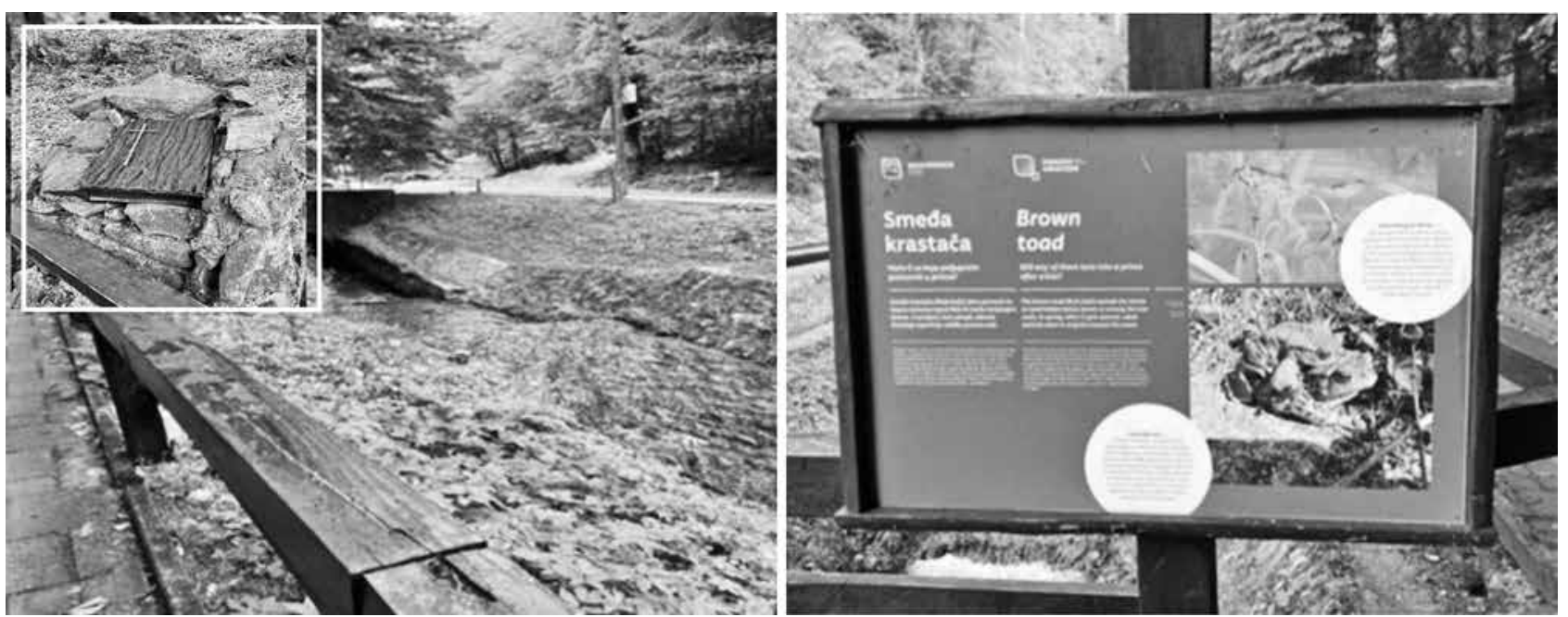

prirode Medvednica omogućen je pješacima, biciklistima, posjetitelji mogu doći i osobnim automobilima i javnim prijevozom (autobus), a uskoro će u pogonu biti i žičara. Sadržaji koji se nude posjetiteljima su: poučne staze, planinarske staze, interpretativne šetnje, posjet Medvedgradu, špilji Veternici i rudniku Zrinski. Uz to, tu su i ugostiteljsko-smještajni kapaciteti, kojima ne upravlja Javna ustanova Parka prirode Medvednica, te planinarski domovi. Infocentar Bliznec je (slika 2) jedan od glavnih ulaza u Park prirode Medvednica.

$\mathrm{U}$ tom modernom kiosku prodaju se suveniri i izletničke karte Medvednice, daju se upute posjetiteljima te leci i brošure u kojima su predstavljeni glavni sadržaji i atrakcije Medvednice. Pored infocentra Bliznec nalazi se zanimljiv labirint Natura 2000 u kojem su prikazane neke od biljnih i živo-

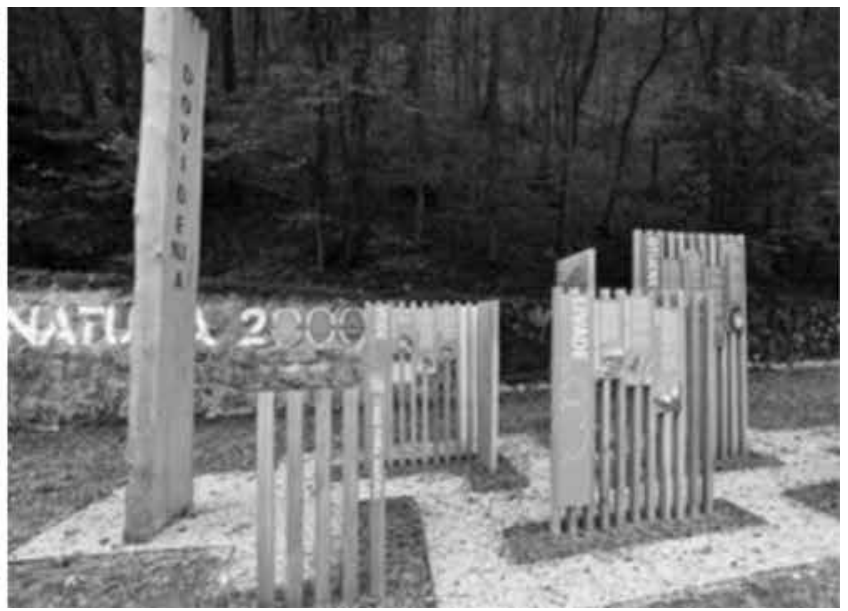

Slika 3. Poučna staza Bliznec

Fig. 3 Educational trail Bliznec 
tinjskih vrsta i staništa zbog kojih je Medvednica postala važan dio europske slagalice u okviru te ekološke mreže, odnosno najveće mreže zaštićenih područja u svijetu. Pored kioska nalazi se i geološki stup pomoću kojega je prikazana složena geološka povijest. Kiosk infocentra izrađen je od drva i stakla, a šumska staza Bliznec i labirint Natura 2000 izrađeni su od drva iz samoga Parka prirode. Stijene su kronološkim redom ugrađene u stup od najstarijih glinenih škriljevaca do najmlađih litotamnijskih vapnenaca. Kod infocentra Bliznec počinje i zanimljiva šumska staza Bliznec koja pruža jedinstven doživljaj, jer prelazi i vijuga preko potoka, a u potpunosti je prilagođena i osobama s invaliditetom $i$ bila je prva staza u Hrvatskoj uređena za osobe s posebnim potrebama (PP Medvednica 2021). Staza Bliznec prilagođena je i nagibom i podlogom koja je neklizajuća, a cijelu stazu prate poučne ploče koje imaju i dijelove na Brailleovu pismu, čak je i križni put koji kreće od tamo obilježen Brailleovim pismom.

$\mathrm{Na}$ Medvednici postoje 72 (po nekim autorima mapa i 82) planinarske staze različitih duljina i okvirnoga vremena potrebnoga za prolazak, a razlikuju se i po slobodnoj procjeni težine staze $u$ rasponu od 1 (najlakša) do 5 (najteža). Neke od planinarskih staza su: Jablanovec - PK »Kameni svati«, staza duga $5,5 \mathrm{~km}$ koja se može proći prema procjeni za dva sata i srednje je težine, Mikulići - PD »Risnjak« staza duga $3,8 \mathrm{~km}$ za čiji je prolazak potrebno sat vremena i trideset minuta, a također je srednje težine. Bidrovec/Vidovec - PD »Gorščica« je jedna od najtežih staza, odnosno staza s ocjenom 5 , a duga je 2,5 km. Budući da planinarske staze započinju od naselja, one $u$ podnožju većinom kreću od asfaltiranih prometnica, a ulaskom $\mathrm{u}$ šumu staze su održavane uzastopnim prolaskom samih planinara, a na nekim dijelovima pojedine staze prelaze i preko makadamskih cesta (PP Medvednica 2021).

Biciklističke rute označene su brojevima od 1 do 9 i trasirane su tako da među njima postoje dodirne točke na kojima se može prelaziti s jedne rute na drugu i tako kombinirati rutu. Sve su rute kružne i opisane su u jednom smjeru, a tako su i označene. Rute su markirane bijelom markacijom bicikla i brojem rute (PP Medvednica 2021).

U Parku je postavljen velik broj klupa i nekoliko odmorišta u šumi i uz cestu, a materijal koji prevladava je prirodni: drvo ili lokalni kamen.

Razlozi koji govore za to da se estetskomu i rekreacijskomu pristupu uređivanja šumskih površina na Medvednici treba posvetiti danas veća pažnja sve su jači i jači:

$\Rightarrow$ gradsko se stanovništvo stalno povećava

$\Rightarrow$ dohodak po stanovniku u Gradu Zagrebu u stalnom je porastu tako da građani odvajaju jedan dio sredstava za rekreaciju

$\Rightarrow$ produktivnost iz dana $u$ dan raste pa ostaje slobodnoga vremena za rekreaciju

$\Rightarrow$ motorizacija, mehanizacija i razvoj prometnih sredstava približio je čovjeka Medvednici

$\Rightarrow$ nagomilavanje gradskoga stanovništva, prenapučenost, industrijska djelatnost, stambena kriza itd. tjeraju gradskoga čovjeka u šumu (Klepac 1964).
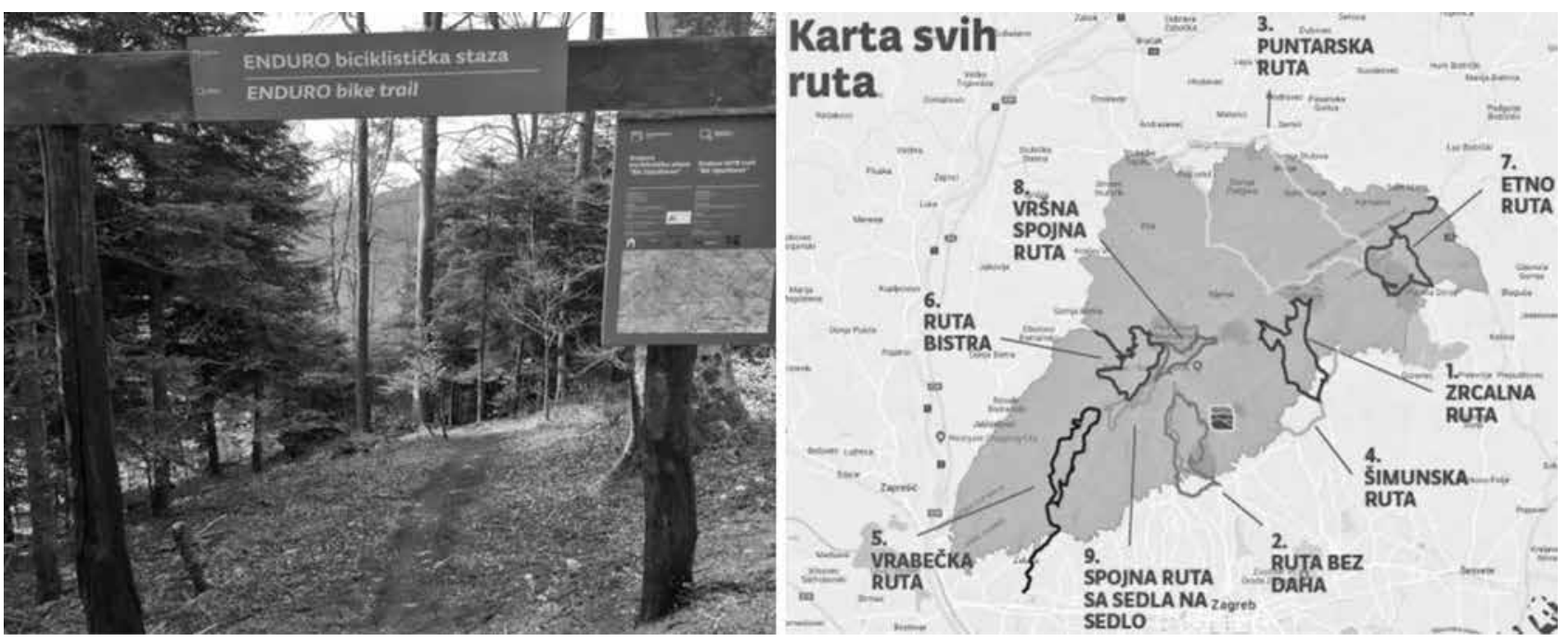

Slika 4. Biciklističke rute u Parku prirode Medvednica

Fig. 4 Bicycle routes within Medvednica Nature Park 

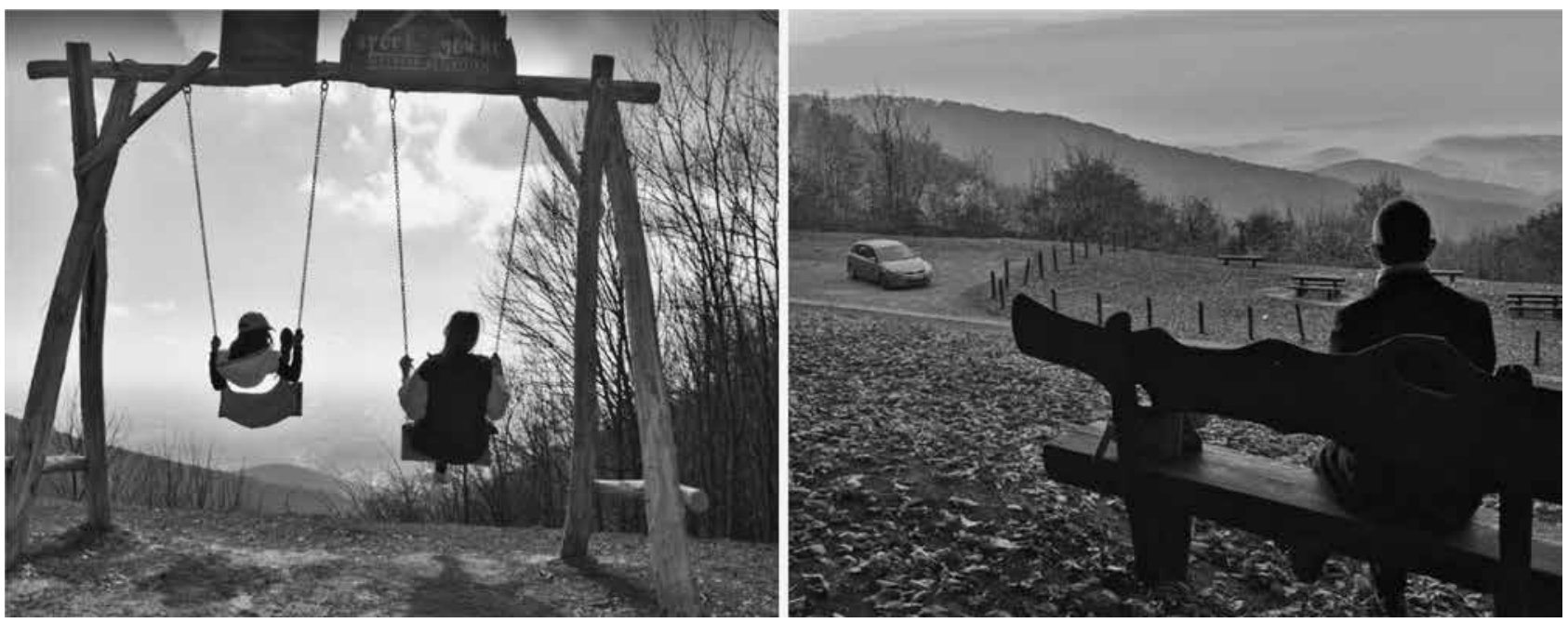

Slika 5. Drvene klupe i odmorišta u Parku prirode Medvednica Fig. 5 Wooden benches and restrooms in Medvednica Nature Park

Radi sprečavanja erozije i loše prognoze zbog današnjega stanja šuma na Medvednici nisu poželjni tehnički zahvati koji bi mogli ugroziti bilo stanište bilo šumu u Parku. Potrebno je zabraniti svaku sječu koja se ne odnosi na uzgojne mjere u šumi. Ovdje se misli na gradnju cesta, zgrada, prosijecanje šuma radi skijaških staza, vučnica i drugo. Najnužnija izgradnja, potrebna za održavanje i funkcioniranje postojećih objekata, može se obaviti tako da se ne oštete stabla i ne naruši rizosfera šume. Opterećenost prostora Zagrebačke županije naglom urbanizacijom i različitom industrijom, izgradnjom magistralnih i drugih prometnica, kanala, dalekovoda i drugoga, stvara pritisak koji se itekako osjeća u zagrebačkom prstenu te uzrokuje nestanak i zagađenje poljoprivrednoga zemljišta, sušenje i propadanje šumskih ekosustava i druge negativne posljedice (Tustonjić i dr. 1999).

\section{Park prirode Lonjsko polje - Lonjsko Polje Nature Park}

Mozaik koji je svojim sadržajem mamac za brojne biljne i životinjske vrste, koje su drugdje u Europi gotovo pa nestale, sastoji se od poplavnih hrastovih šuma ispresijecanih pašnjacima i od otvorenih poplavnih površina. U Parku su dopuštene radnje koje ne utječu na njegovu ulogu i na njegove bitne značajke. Male seoske cjeline i njihove socijalne strukture, tradicionalna poljoprivreda i zaštita kulturne baštine jesu specifičnost Lonjskoga polja. U Parku prirode Lonjsko polje prevladava šumska vegetacija velike bioraznolikosti, bogatstvo zajednica i očuvanost šum- skih kompleksa. Oko $60 \%$ površine Parka prirode (22 500 ha) čine šume kojima upravljaju Hrvatske šume prema načelima održivoga gospodarenja (Prostorni plan Parka prirode Lonjsko polje 2010).

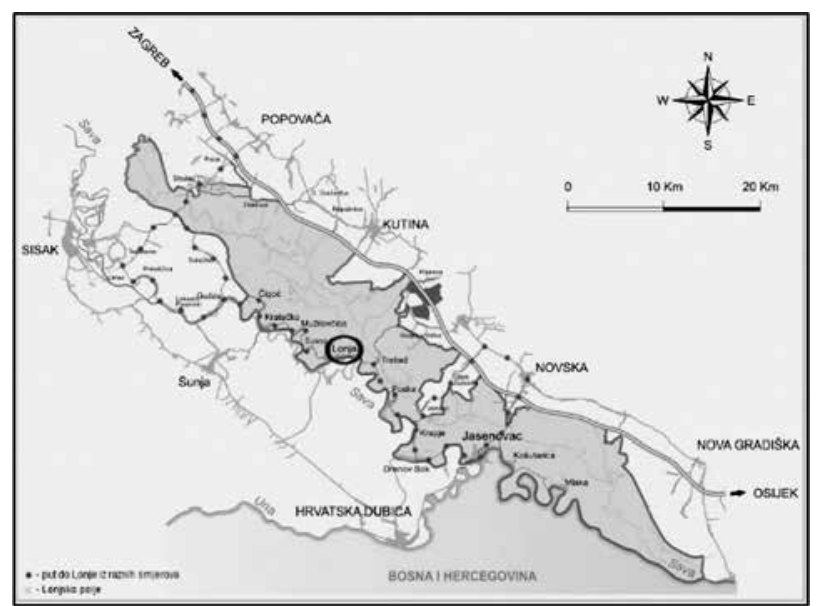

Slika 6. Karta naselja i gradova na području Parka prirode Lonjsko polje

Fig. 6 Map of settlements and towns in the area of Lonjsko Polje Nature Park

Šume su u Parku prirode više ili manje ovisne o poplavama i razini podzemne vode. U depresijama i područjima s nižom nadmorskom visinom prevladavaju šumske zajednice u kojima dominiraju hrast lužnjak, crna joha, poljski jasen i nizinski brijest. Te su šume $u$ prošlosti bile redovito poplavljivane, no danas su rjeđe plavljene (ovisno o terenu i udaljenosti od rijeke). Mogu se pak održavati samo na visokoj 
razini podzemne vode i zbog zadržavanja oborinske vode. Poplavne šume hrasta lužnjaka zauzimaju oko 9700 ha, što je oko 19 \% površine Parka prirode. Rasprostranjene su na sjevernom kraju Parka te u središnjem dijelu Parka, južno od Lipovljana. Poplavne šume crne johe i poljskoga jasena zauzimaju oko 7200 ha, a najveći kompleksi nalaze se u središnjem i južnom dijelu Parka (Bogović i Hima 2008).

Sukladno Nacionalnoj klasifikaciji staništa na području Lonjskoga polja osim prirodnih i/ili do prirodnih staništa nalaze se $\mathrm{i}$ antropogeno uvjetovana staništa na kojima prirodno obitavaju brojne biljne i životinjske svojte karakteristične za europsko-sjevernoameričku regiju. Najveću površinu Parka zauzimaju nizinske poplavne šume, potom antropogeno uvjetovani stanišni tipovi, izgrađena i industrijska staništa te mozaici kultiviranih površina. Od drvenastih vrsta najrašireniji su hrast lužnjak (Quercus robur) i obični grab (Carpinus betulus). Osim kopnenih staništa PP Lonjsko polje prožet je stalnim i povremenim vodama stajačicama, kanalima, povremenim vodotocima i tekućicama, koji mogu biti manje ili više obrasli vegetacijom, koji čine izvor bioraznolikosti takvih područja. Protežući se na preko 50650 ha Lonjsko polje čini jedno od najvećih nereguliranih poplavnih nizina u Europi, kompleks poplavnih šuma, močvara, livada, bara i riječnih rukavaca te poljoprivrednih površina (Gugić i dr. 2008). Na šumsku vegetaciju od biotskih čimbenika najviše utječe čovjek koji djeluje na izgled nizinskih šuma koje rastu u Lonjskom polju. Taj je utjecaj uglavnom negativan i on se odnosi na prekomjernu i nereguliranu sječu, ispašu domaćih životinja te provođenje hidromelioracijskih mjera (Ptić 2019). Pravilnik o popisu stanišnih tipova, karti staništa te ugroženim i rijetkim stanišnim tipovima (NN 2014) u Prilogu III donosi popis ugroženih i rijetkih stanišnih tipova zastupljenih u Republici Hrvatskoj značajnih za ekološku mrežu Natura 2000 na kojem se nalaze i 91F0 - Poplavne miješane šume Quercus robur, Ulmus laevis, Ulmus minor, Fraxinus excelsior, Fraxinus angustifolia te prioritetni stanišni tip 91E0 - Aluvijalne šume (Alno-Padion, Alnion incanae, Salicion albae) čije se sastojine nalaze i na području PP Lonjsko polje. Prema Pravilniku o popisu stanišnih tipova i karti staništa (NN 27/21), Nacionalne klasifikacije staništa RH najzastupljenija kategorija šuma je šuma poljskoga jasena s kasnim drijemovcem (E.2.1.7.) koja pokriva $22 \%$ površine Parka (Kušan i dr. 2019).

U Parku su izgrađene pješačke i edukativne staze, prihvatni centri, suvenirnice, osigurana plovidba čamcima iz pristaništa u Krapju, ali i autobusne linije za vrijeme održavanja manifestacija, omogućen je najam bicikla i kanua te su organizirane biciklijade. Ta infrastruktura i sadržaji, uključujući i edukativne programe, osnova su za pružanje višednevne usluge i zadržavanje posjetitelja na tom području u trajanju od nekoliko dana. Posjetitelji u najvećem postotku uz pješačenje koriste vidikovce i promatranje ptica kao rekreativni sadržaj.
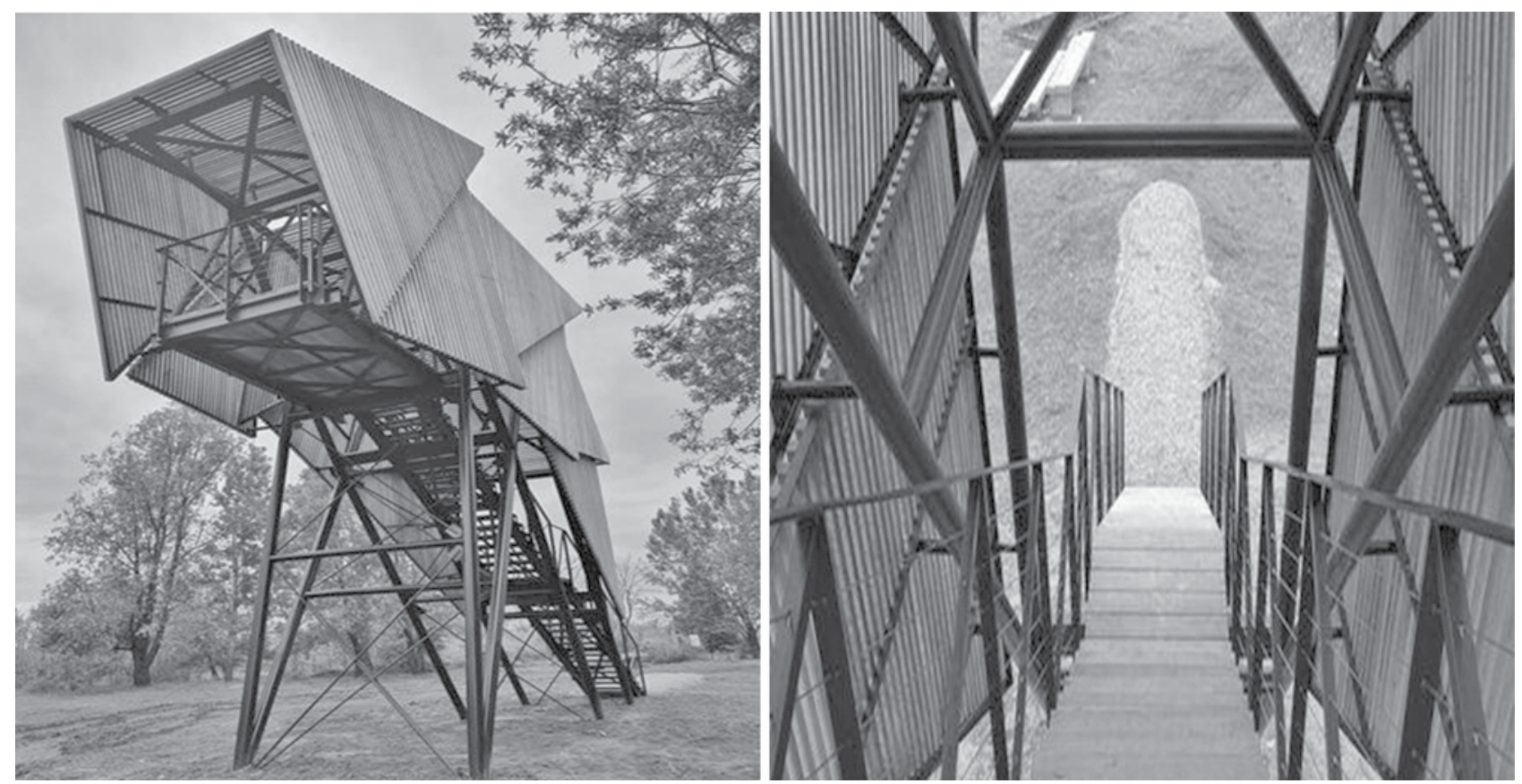

Slika 7. Promatračnica »Ptica kosac»

Fig. 7 Observatory »Ptica kosac» 
Uz autobus prijevoz je moguć kanuima i čamcima koji se mogu unajmiti s pristaništem u Krapju i definiranim voznim redom. Na području PP Lonjsko polje prelazak preko rijeke Save moguć je i skelom. Danas su u funkciji još dvije tradicijske skele. Jedna je u selu Kratečko, a druga u selu Lukavec kod Gušća. Skele pokreće riječna struja. Edukativno-turistička skela »Vodomar « ima pristanište u Drenovu Boku i Krapju. Dugačka je $15 \mathrm{~m}$, a registrirana je za kapacitet 25 osoba te nudi mogućnost ugodne vožnje na rijeci Savi. Osim skele kao novost su čamci na solarni pogon (PP Lonjsko polje 2021). uzvišenim područjima s obzirom na to da je riječ o nizinskom području. U prošlosti su uz klupe neizostavno postavljani i koševi za otpatke, što se danas zbog raznošenja samoga otpada po parkovima više ne prakticira te se uklanjaju i već postojeći koševi. Posjetitelji su Parka prirode Lonjsko polje u prvom redu školska djeca, studenti i stručne grupe (gotovo $80 \%$ ), individualni posjetitelji i obitelji s djecom, promatrači ptica (birdwatcheri), umirovljenici, organizirane grupe i lovci koji dolaze iz lovačkih udruga i njihov posjet nije $u$ organizaciji Ustanove. Radi jačanja ekonomskoga prosperiteta lokalnoga sta-
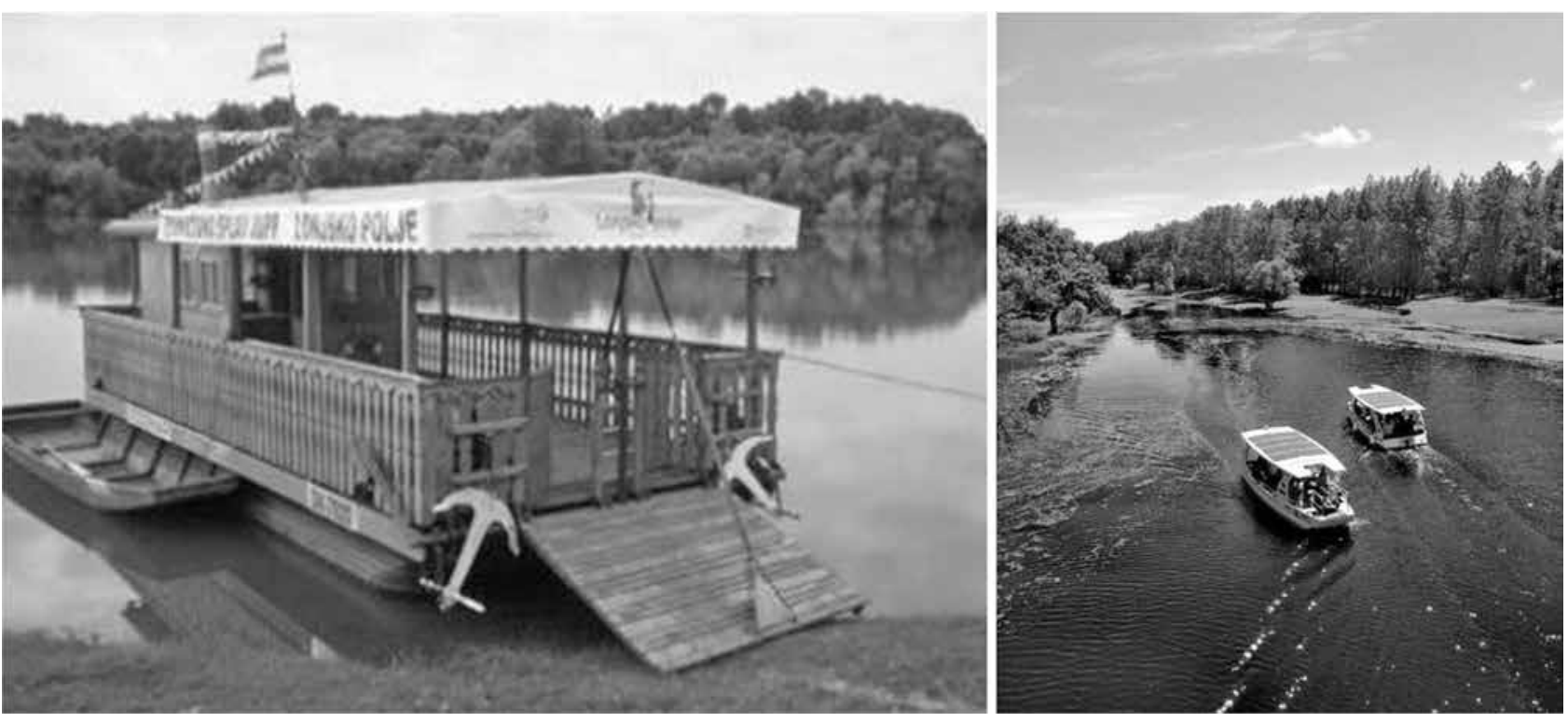

Slika 8. Skela i čamci na solarni pogon za prijevoz vodenim površinama

Fig. 8 Ferry and solar powered boats for water transport

Vidikovci pružaju jedinstven pogled na Park prirode Lonjsko polje te ih definiramo kao povišeno mjesto koje omogućuje dobar pogled odnosno mjesto koje je uređeno za promatranje okoliša. U Lonjskom polju postoje tri vidikovca koja su građena na tlu kao dio krajolika uz stazu. Vidikovac Osekovo je građen kao replika vojnih stražarnica iz doba Vojne krajine, dok su vidikovci Rezac i Žličarka drvene konstrukcije i može im se pristupiti pješačkim i biciklističkim stazama (PP Lonjsko polje 2021).

Uza sve te postoje i druge aktivnosti, kao što su: panoramska vožnja turističkim vlakićem kroz Krapje, vožnja golf-automobilom, zipline i mnoštvo kreativnih radionica. Staze i putovi su izgrađeni od pješčanoga i šljunčanoga materijala, pojedini putovi su drvene konstrukcije kao i mostići. Stolovi i klupe su također od prirodnoga materijala i nalaze se na novništva i gospodarstva uopće, na području Parka Javna ustanova želi imati što više posjetitelja koji će više dana ostati u Parku. U skladu s tim Ustanova planira kroz nekoliko akcijskih planova provesti radionice s lokalnim stanovništvom radi stvaranja turističkih ponuda s višednevnim boravkom u Parku namijenjenih raznim ciljnim skupinama - obiteljima, umirovljenicima, zaposlenicima na team buildingu, ljubiteljima promatranja ptica i biciklistima (Vugrinović i dr. 2012).

Postoje dva osnovna tipa staza, a to su pješačke i biciklističke staze. Pješačke se staze dijele prema širini (za dvije osobe koje se jednosmjerno kreću jedna uz drugu) na: loše $(80-100 \mathrm{~cm})$, bolje $(110 \mathrm{~cm})$, najbolje $125 \mathrm{~cm}$; prema uzdužnom nagibu: staze $\mathrm{u}$ nagibu do $5^{\circ}$ ili $9 \%$, staze u nagibu $7-9^{\circ}$ ili $12-15 \%$ i staze u nagibu do $14^{\circ}$ ili $25 \%$ (Nevečerel i Lepogla- 

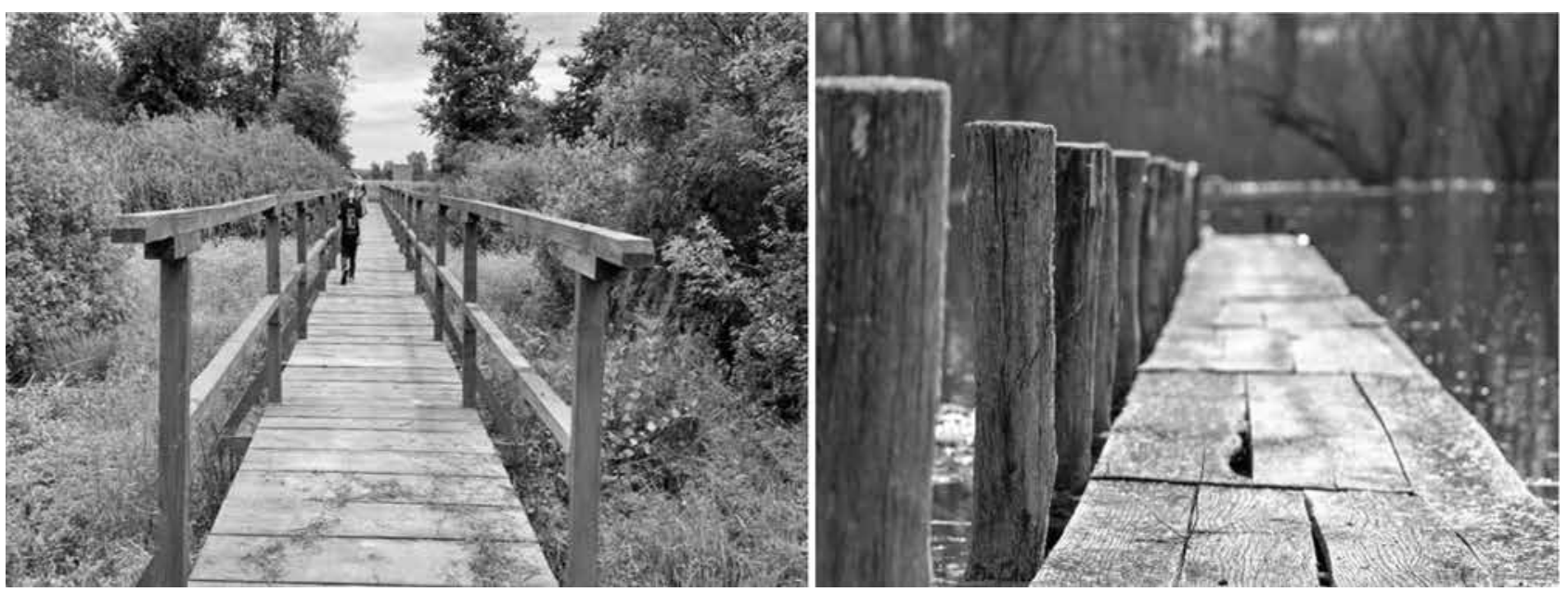

Slika 9. Infrastruktura od prirodnoga materijala: drveni most i drveno pristanište čamaca

Fig. 9 Infrastructure of natural material: wooden bridge and wooden boat dock

vec 2020). U Lonjskom su polju određene zone posjećivanja, 5 glavnih i 12 sporednih ulaza u Park. Kao glavni ulazi u Park određeni su: Krapje, Čigoč, Kutina, Osekovo i Repušnica. Oni su mjesta na kojima je organiziran posjetiteljsko-informativni centar kojim upravlja Javna ustanova Parka prirode Lonjsko polje. Neki sadržaji koje nude posjetiteljsko-informativni centri su: dvorana za prezentaciju i edukaciju, edukacija na otvorenom, izložbeni prostor, informativni punkt, suvenirnica, postaja službe nadzora Javne ustanove Parka prirode Lonjsko polje i brojni drugi sadržaji namijenjeni prihvatu i edukaciji posjetitelja. Kao ostali ulazi u Park određeni su ovi ulazi: Piljenice, Kraljeva Velika, Opeke, Svinjičko, Stružec, Donja Gračenica, Stara Gradiška, Kratečko-skela, Jasenovac jug, Novska i Plesmo (Vugrinović i dr. 2012).

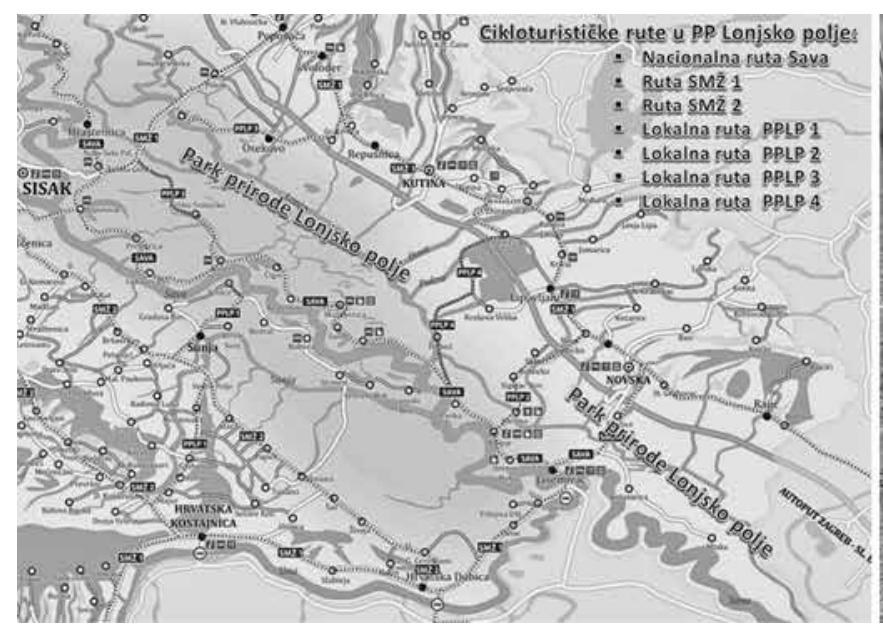

Od pješačkih staza u PP Lonjsko polje postoje: Staza graničara, Staza Posavca, Tenina staza i Koščeva staza.

Staza Posavca nudi šetnju u trajanju od dva do dva i pol sata te je dugačka $4200 \mathrm{~m}$. Staza je poplavnoga područja te se tamo nalazi osmatračnica za promatranje ptica i domaćih životinja na slobodnoj ispaši. Značajno je kolebanje razine vode te je potrebna izvedba preljevnica. Staza je kružnoga karaktera i na njoj je postavljeno pet poučnih ploča. Koščeva je staza kružnoga koncepta i kreće iz prijamnoga centra Repušnica te vodi uz sjeverni nasip retencije uz poplavne livade košanice i pašnjake. Za takvo je područje karakteristična razvijena hidrografska mreža, gdje se pojavljuju stalni vodotoci velikoga protoka te je potrebna izgradnja mostova. Mostovi

Slika 10. Biciklističke rute u Parku prirode Lonjsko polje

Fig. 10 Bicycle routes in Lonjsko Polje Nature Park

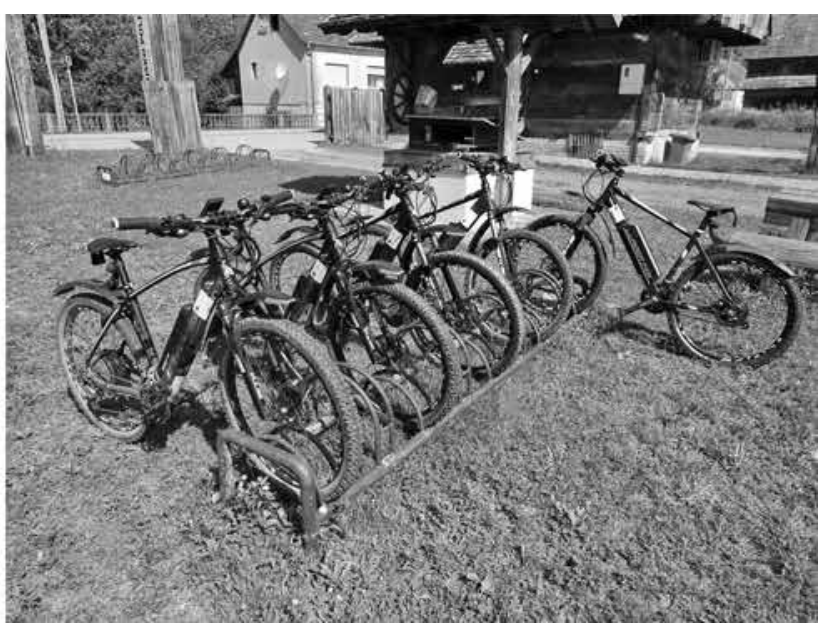


su drveni i u skladu s prirodnom estetikom. Duljina je staze $5 \mathrm{~km}$ te ide po postojećem šumskom i poljskom putu, a trajanje je obilaska oko dva sata (PP Lonjsko polje 2021).

Na području samoga Parka posjetitelji mogu koristiti bicikl kao prijevozno sredstvo. Biciklističke staze prema širini dijele se na: jednotračnu stazu $(80-100 \mathrm{~cm})$, dvotračnu $(150-180 \mathrm{~cm})$ i dvotračnu dvosmjernu stazu od 250 do $280 \mathrm{~cm}$ (Nevečerel i Lepoglavec 2020). Cikloturističke rute u Parku prirode Lonjsko polje Posavinu povezuju s Moslavinom i Pounjem. Visinska razlika gotovo je neprimjetna, jer nema većih uspona, a promet na cestama kojima rute prolaze, osim na ruti Sisačko-moslavačke županije 1, veoma je rijedak. To rute čini iznimno sigurnima za vožnju. Sve su rute vrlo dobro označene cikloturističkom signalizacijom, a na pojedinim lokacijama uređene su odmorišne postaje. Opremljene su stolovima, klupama i kantama za otpad. Bicikl je moguće iznajmiti na tri lokacije prijamnih centara: Krapje, Čigoč i Repušnica. U Parku se nalazi devet biciklističkih ruta od kojih je pet obiteljskih (PP Lonjsko polje 2021).

\section{Zaključak - Conclusion}

Promatrajući ta dva parka prirode koji su na prvu čiste suprotnosti što se tiče reljefa, ipak nailazimo na dosta sličnosti osobito u području infrastrukture koja je građena od prirodnoga materijala, čime infrastrukturni elementi ne odudaraju od okolice i ne okreću fokus na sebe, već ostaje na prekrasnoj prirodi. PP Medvednica je planina koja najbolje zasad odolijeva urbanim pritiscima okolice i gdje vlada takva klima da omogućuje doživljaje u razlikama kroz sva četiri godišnja doba. PP Lonjsko polje je jedno od europskih najvećih očuvanih poplavnih područja čime zauzima prva mjesta na europskoj karti prirodnih specifičnosti. Najveće sličnosti parkova ogledaju se u smjeru upravljanja područjem, koje se sve više okreće prema aktivnomu turizmu pa je sve više biciklista, pješaka, trkača i dr. Sadržaji se povećavaju, što zasigurno privlači veći broj posjetitelja, ali se time i oduzima dragocjeno zaštićeno područje. Dizajn krajolika, terena, igrališta, sportskih zona i usluga utječe na stupanj iskoristivosti parka. Veći je i broj staza kroz park čime se posjetitelji usmjeravaju prema točkama interesa kako ne bi dolazilo do nepoželjnih »lutanja« posjetitelja. Takav način planiranja staza kroz okolišno osjetljiva područja može imati negativne utjecaje, uključujući uznemiravanje divljih životinja, gaženje vegetacije, eroziju staza i širenje invazivnih vrsta. Kada se park koristi, to znači da mu je svakako potrebno i povremeno održavanje kako bi njegovi prostori i dalje privlačili posjetitelje, a i radi očuvanja prirodnoga ekosustava parka. Iz svega toga izuzetno je važno da državno tijelo odgovorno za razvoj parkova stvori održivu ravnotežu između korištenja sadržaja parkova i očuvanja prirode.

\section{Literatura - References}

Bogović, E., V. Hima, 2008: Vodič za pješačke i cikloturističke staze. https://pp-lonjsko-polje.hr/wp-content/ uploads/2019/04/Vodic-za-pjesacke-i-cikloturisticke-staze-u-PPLP.pdf

Đuričić-Kuric, T., 2014: Međunarodni znanstveno stručni skup »Poplavne šume«. https://www.sumari.hr/sumlist $/ 201403$.pdf\#page $=99$

Gugić, G., V. Hima, Z. Posavec, E. Bogović, D. Ivaštinović, 2008: Park prirode Lonjsko polje - Živući krajobraz i poplavni ekosustav srednje Posavine - Plan upravljanja. https://www.vusz.hr/Cms_Data/Contents/VSZ/Folders/ dokumenti/javanustanovazaupravljanjezasticenimprirodnimvrijednostima/zakonskaregulativa/ contents/ PX327RM9DRWJZHNG/2011-3-24-3874773-parkprirodelonjskopolje-planupravljanja.pdf

IUCN, 2021: https://www.iucn.org/.

Klepac, D., 1964: Smjernice o estetskom i rekreativnom uređenju šuma Medvednice. Šumarski list 88(1-2): 1-9.

Kušan, V., T. Birov, J. Mihalić, M. Petković, S. Sviben, V. Kutnjak, N. Jantol, V. Pavić, K. Hocenski, 2019: Studija upravljanja posjetiteljima PP Lonjsko polje. PP Lonjsko polje. https://pp-lonjsko-polje.hr/wp-content/uploads/2020/01/Studija-upravljanja-posjetiteljima-za-Park-prirode-Lonjsko-polje-1.pdf

Majer, D., 1980: Šume Medvednice kao rekreacijsko područje Grada Zagreba. Šumarski list 104(7-8): 299-338.

MINGOR, 2021: Ministarstvo gospodarstva i održivog razvoja. Web stranica: https://mingor.gov.hr/o-ministarstvu-1065/djelokrug/uprava-za-zastitu-prirode-1180/zasticena-podrucja/parkovi-prirode/1196 (pristupljeno: 28. 9. 2021)

Nevečerel, H., K. Lepoglavec, 2020: Parkovna tehnika i niskogradnja. Interna skripta, Fakultet šumarstva i drvne tehnologije Sveučilišta u Zagrebu.

Opačić, V. T., D. Curić, M. Jandras, K. Kutle, N. Marijan, I. Mirt, D. Perković, I. Vodanović, 2014: Zaštićena područja kao rekreacijske zone grada - primjer Parka prirode Medvednica. Prirodoslovno-matematički fakultet Sveučilišta u Zagrebu. https://hrcak.srce.hr/index.php?show=clanak\&id_clanak_jezik=186528

Ožura, M., L. Vargović, A. Starešinić, 2012: Analiza pristupačnosti zelenim površinama osobama s invaliditetom $u$ 
Hrvatskoj. Zbornik radova Zaštita na radu i zaštita zdravlja, Veleučilište u Karlovcu, Karlovac.

Park prirode Lonjsko polje, 2021: https://pp-lonjsko-polje. hr/ (pristupljeno: 28. 9. 2021)

Park prirode Medvednica, 2021: https://www.pp-medvednica.hr/ (pristupljeno: 28. 9. 2021)

Pravilnik o popisu stanišnih tipova, karti staništa te ugroženim i rijetkim stanišnim tipovima. NN 88/2014. https:// narodne- novine.nn.hr/clanci/sluzbeni/2014_07_88_1782. html

Pravilnik o popisu stanišnih tipova i karti staništa. NN 27/2021. https://narodne-novine.nn.hr/clanci/sluzbeni/2021_03_27_588.html.

Prostorni plan Parka prirode Lonjsko polje, 2010: Ministarstvo zaštite okoliša, prostornog uređenja i graditeljstva,
Zagreb - Sisak. https://pp-lonjsko-polje.hr/wp-content/ uploads/2019/05/2-Knjiga-II-Obrazlozenje_i_obvezni_ prilozi-NN37_2010.pdf

Ptić, A., 2019: Monitoring šumske vegetacije na području Lonjskog polja. Diplomski rad, Šumarski fakultet Sveučilišta u Zagrebu. https://repozitorij.sumfak.unizg.hr/ islandora/object/sumfak:1624/datastream/PDF

Tustonjić, A., J. Pavelić, N. Farkaš-Topolnik, T. Đuričić-Kuric, 1999: Šume unutar prostornog plana zagrebačke županije. Šumarski list, 123 (9-10): 469-485.

Vugrinović, A., P. Galeski, Lj. Horvat, M. Tomašić, 2012: Marketing plan područja Parka prirode Lonjsko polje. Javna ustanova Park prirode Lonjsko polje. https://www. smz.hr/images/stories/eu/Lonjsko\%20polje_MARKETING\%20PLAN_final.pdf

\section{Abstract}

\section{Technical Implementation of Infrastructure and other Facilities in Nature Parks Lonjsko polje and Medvednica}

Forests and forest land today provide multiple benefits to people who visit nature. Due to fast-paced and stressful way of life, people need to get away from the city crowds, and such places are increasingly found in nature parks. The forests of the nature park can truly give the desired peace to the visitor, and Lonjsko polje and Medvednica are two parks that consist of large but different forest areas. They are also two very interesting nature parks, each specific in its own way. Medvednica Nature Park is a recreational area in the immediate vicinity of the city agglomeration of millions, which provides great opportunities for the development of recreational activities. The forests on Medvednica are not only used for the production of wood assortments but at the same time, the citizens of the city of Zagreb and other people use them for their daily recreation. Access to the Medvednica Nature Park is provided for pedestrians, cyclists, visitors can also come by car and public transport (bus), and a cable car will soon be in operation. Facilities offered to visitors are educational trails, hiking trails, interpretive walks, a visit to Medvedgrad, Veternica Cave, and Zrinski Mine. In addition, there are restaurants and accommodation facilities and mountain lodges.

Lonjsko Polje Nature Park is a floodplain area dominated by pedunculate oak, black alder, field ash, and lowland elm. Hiking and educational trails, reception centers, souvenir shops have been built, boating from the port in Krapje has been ensured, as well as connections by bus lines. This infrastructure and facilities, including educational programs, are the basis for providing multi-day service and retaining visitors to the area. The largest percentage of visitors, in addition to hiking, use lookouts and bird watching as recreational possibilities in Lonjsko Polje Nature Park.

Through the description of each individual nature park, the article points out the important differences between the two areas, but also the similarities that connect them in some way.

Keywords: nature park, Medvednica, Lonjsko polje, design of park spaces, forestry, recreation 
Adrese autorâ - Authors' addresses:

Tea Jakobašić, univ. bacc. ing. silv. e-pošta: tea1996.jakobasic@gmail.com Đure Deželića 77 44320 Kutina, Selište HRVATSKA

Zdravka Klišanin, univ. bacc. ing. silv. e-pošta: zdravkaklisanin58@gmail.com Stjepana Radića 14 80101 Livno BOSNA I HERCEGOVINA

Izv. prof. dr. sc. Hrvoje Nevečerel e-pošta: hnevecerel@sumfak.hr Doc. dr. sc. Kruno Lepoglavec* e-pošta: lepoglavec@sumfak.hr Sveučilište u Zagrebu Fakultet šumarstva i drvne tehnologije Svetošimunska cesta 23 10000 Zagreb HRVATSKA

* Glavni autor - Corresponding author 